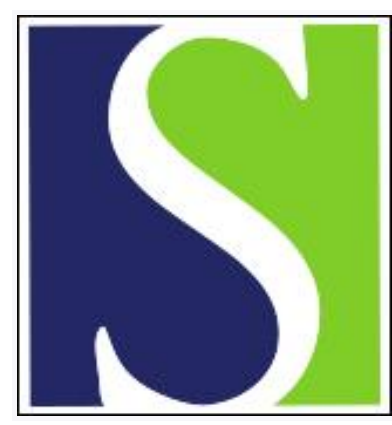

Scand J Work Environ Health 1989;15(6):395-403

https://doi.org/10.5271/sjweh.1833

Issue date: Dec 1989

Shift work, fetal development and course of pregnancy.

by Nurminen $T$

Affiliation: Institute of Occupational Health, Department of Epidemiology and Biostatistics, Helsinki, Finland.

The following article refers to this text: 2018;44(4):403-413

This article in PubMed: www.ncbi.nlm.nih.gov/pubmed/2617256

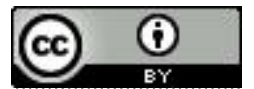




\title{
Shift work, fetal development and course of pregnancy
}

\author{
by Tuula Nurminen, $\mathrm{MSc}^{1}$
}

\begin{abstract}
NURMINEN T. Shift work, fetal development and course of pregnancy. Scand $J$ Work Environ Health 1989;15:395 - 403. Information on 1475 mothers of infants with selected structural malformations and an equal number of mothers of "normal" babies was analyzed for a possible relationship between shift work and adverse pregnancy outcome or a complicated course of pregnancy. The primary data were obtained from the Finnish Register of Congenital Malformations supplemented by special interviews on the mothers' work conditions. No signs of a teratogenic risk were observed. The relationship between course of pregnancy and outcomes other than malformations was determined from the noncase mothers' experience. Threatened abortion and pregnancy-induced hypertension were not associated with rotating shift work alone, but in a noisy work environment moderate risks could not be ruled out. Rotating shift work was associated with a slight excess of babies small for their gestational age independently of noise exposure. The results suggest that further studies on the effects of different work schedules on pregnancy are worth consideration.
\end{abstract}

Key terms: birth defects, birthweight, length of gestation, malformations, occupation, pregnancy-induced hypertension, threatened abortion, vaginal bleeding.

Few investigations have been made on the possible relationship between shift work and fetal development or course of pregnancy. In a Japanese study (1) shift and night workers reported spontaneous abortion more frequently than day workers. Shift work in laboratories was related to a clearly higher rate of spontaneous abortion in a Swedish study (2). But this relation was not confirmed in a later investigation (3), and only a slightly increased risk was associated with work entailing irregular hours or rotating shifts as compared with day work only. In a study in Montreal (4) rotating or irregularly changing shift work was related to spontaneous abortion, and the association was confirmed in a second analysis of the same data. Shift work and night work was associated with preterm delivery in a French study (5). However, another French study (6) found no relation between preterm delivery or low birthweight and night work. In the Montreal study (7) changing shift work was related to preterm birth and low birthweight, but not consistently. Because of the large overlap between preterm birth and low birthweight, the data of the Montreal study were analyzed further, and gestational age was allowed for when birthweight was the outcome. The results suggested that shift work retarded fetal growth and increased the risk of preterm birth (8). The results of the later Swedish study (3) supported the hypothesis that irregular work schedules might have a negative influence on birthweight. Institute of Occupational Health, Department of Epidemi-
ology and Biostatistics, Helsinki, Finland.

Reprint requests to: Ms T Nurminen, Department of Epidemiology and Biostatistics, Institute of Occupational Health, Topeliuksenkatu 41 a A, SF-00250 Helsinki, Finland.
To investigate the effects of shift work on teratogenic risk, threatened abortion, pregnancy-induced hypertension, length of gestation, and birthweight, the present study scrutinized the experience of 1475 mothers of infants with selected structural malformations and an equal number of mothers of noncase babies. The study was part of a project whose original goal was to explore the possible role of occupational factors in the occurrence of birth defects (9).

\section{Subjects and methods}

\section{Birth defects}

The source information of the study was the Finnish Register of Congenital Malformations between June 1976 and December 1982. The data included 365 defects of the central nervous system, 581 orofacial clefts, 360 structural defects of the skeleton, 169 cardiovascular malformations, and 1475 noncase babies whose deliveries had preceded the case deliveries in the same maternity health care district (9). The mothers of the time- and area-matched case-noncase pairs of babies were interviewed by means of standard Register procedures about particulars of the latest and previous pregnancies, diseases, consumption of drugs and alcohol, smoking habits, etc (10). The Register data were supplemented with interviews on the mothers' work conditions. Two trained interviewers from the Finnish Institute of Occupational Health carried out the interviews. (For details, see references 9, 11, and 12.)

The special interview started with a question inquiring if the mother had worked during her pregnancy most of the time, only temporarily, or not at all. In addition to information on the employer, job title, and 
Table 1. Occupational classification of the mothers in shift work duririg early pregnancy.

\begin{tabular}{|c|c|c|c|c|c|}
\hline \multicolumn{2}{|c|}{$\begin{array}{l}\text { Major } \\
\text { occupational } \\
\text { group }\end{array}$} & \multirow{2}{*}{$\begin{array}{c}\begin{array}{c}\text { Two- } \\
\text { shift } \\
\text { workers }\end{array} \\
53\end{array}$} & \multirow{2}{*}{$\begin{array}{c}\text { Three- } \\
\text { shift } \\
\text { workers }\end{array}$} & \multirow{2}{*}{$\begin{array}{c}\begin{array}{c}\text { Other } \\
\text { type of } \\
\text { shift } \\
\text { workers }\end{array} \\
111\end{array}$} & \multirow{2}{*}{$\begin{array}{c}\text { Total } \\
171\end{array}$} \\
\hline 0 & $\begin{array}{l}\text { (technical, physical science, social science, } \\
\text { humanistic and artistic work) }\end{array}$ & & & & \\
\hline 1 & (administrative, managerial and clerical work) & 13 & 2 & - & 15 \\
\hline 2 & (sales work) & 8 & - & 2 & 10 \\
\hline 5 & (transport and communication work) & 5 & 4 & 1 & 10 \\
\hline $6 / 7$ & (manufacturing and related work) & 43 & 18 & 2 & 63 \\
\hline 8 & (service work) & 78 & 6 & 3 & 87 \\
\hline \multirow[t]{2}{*}{9} & (work not elsewhere classified) & 8 & 1 & 3 & 12 \\
\hline & Total & 208 & 38 & 122 & 368 \\
\hline
\end{tabular}

a According to reference 14 .

Table 2. Physical load of the mothers who did shift work and those who did nonshift work in the first trimester of their pregnancy.

\begin{tabular}{lrrrrrr}
\hline \multirow{2}{*}{$\begin{array}{l}\text { Mean } \\
\text { physical loada }\end{array}$} & \multicolumn{2}{c}{$\begin{array}{c}\text { Shift } \\
\text { workers }\end{array}$} & & \multicolumn{2}{c}{$\begin{array}{c}\text { Nonshift } \\
\text { workers }\end{array}$} \\
\cline { 2 - 3 } \cline { 6 - 7 } & \multicolumn{2}{c}{$\mathrm{N}^{\mathrm{b}}$} & $\%$ & & $N^{c}$ & $\%$ \\
\hline Sedentary work & 127 & 34.8 & & 1114 & 57.5 \\
$\begin{array}{l}\text { Standing work } \\
\text { Work involving walking }\end{array}$ & 131 & 35.9 & & 443 & 22.9 \\
$\begin{array}{l}\text { Work with a moderate } \\
\text { physical load }\end{array}$ & 81 & 22.2 & & 106 & 5.5 \\
\hline
\end{tabular}

a See reference 15 for a description of the assessment of physical load

b There were three mothers with missing data on physical load.

c There were 43 mothers with missing data on physical load.

time of employment, the mother was asked if she had worked in shifts. Of the mothers, 2073 had worked throughout most of their pregnancy, and 603 had not worked in the first trimester, the risk period for structural malformations (10). In all, 274 mothers had worked temporarily in the first trimester, and the reason for stopping work was the termination of employment for $47 \%$ of these mothers, maternity leave or vacation for $10 \%$, and sick leave or overstrain for $18 \%$. The rest had other reasons or the reason was unknown. The mothers who did not work in the first trimester of pregnancy were excluded from the analyses when birth defects were studied.

Altogether, 368 mothers (16\% of those who had worked) had done shift work during early pregnancy, 41 temporarily and 327 regularly. In the shift work group, $57 \%$ of the mothers had worked in two shifts, $10 \%$ in three shifts, and $33 \%$ had work arrangements that differed in some manner from normal daily work, mainly periodic work. In Finland, the individuals who work in shifts usually do rotating shift work in which the work schedule changes after every week in twoshift work and after $4 \mathrm{~d}$ in three-shift work, while in periodic work the cycle is two or three weeks (13). In the two-shift group almost $40 \%$ had been in service work and about one-half had been in manufacturing or nursing work. Of the mothers working in three shifts, almost one-half had done manufacturing work. The mothers in other types of shift work were mainly in the nursing field. (See table 1.)

According to the classification of socioeconomic status of the Central Statistical Office of Finland (14), most of the mothers $(96 \%)$ in shift work during early pregnancy were lower-level employees with administrative and clerical occupations or manual workers whereas $84 \%$ of the mothers in nonshift work belonged to these categories. None of the women in shift work had been employed in farming. Possible confounding was controlled for in additional analyses in which the subjects were restricted to nonagricultural workers in the two aforementioned socioeconomic classes.

The physical load of the occupational activities of the mothers was evaluated with a standardized method reflecting energy expenditure (15). The group in shift work included relatively more women in standing work and in work involving walking. Nonshift work was more often sedentary, but also moderate physical load was more common in nonshift work (table 2). Over one-half of the mothers in nonshift work with a moderate physical load had worked in agriculture.

Two industrial hygienists independently assessed exposure to noise blindly from a description of the mother's workday and a fixed question on noise exposure (12). In all, $17 \%$ of the mothers in shift work in the first trimester of pregnancy had been exposed to an 8-h equivalent continuous A-weighted sound level $\left(\mathrm{L}_{\text {Aeq }(8-\mathrm{h})}\right)$ of around $80 \mathrm{~dB}$ or higher during early pregnancy, whereas the corresponding percentage was seven in the nonshift group.

Similarly, two industrial hygienists assessed the mothers' solvent exposure on the basis of the workday description and a fixed question on solvent exposure (16). A mother was considered exposed if the continuous concentrations had been at least one-third of the threshold limit values for chemical substances 
Table 3. Background characteristics of the shift and nonshift workers who worked temporarily in the first trimester of their pregnancy and those who worked throughout most of their pregnancy.

\begin{tabular}{|c|c|c|c|c|}
\hline \multirow[b]{2}{*}{$\begin{array}{l}\text { Background } \\
\text { characteristic }\end{array}$} & \multicolumn{2}{|c|}{ Temporary work } & \multicolumn{2}{|c|}{ Regular work } \\
\hline & $\begin{array}{c}\text { Shift } \\
\text { workers } \\
(\mathrm{N}=41) \\
(\%)\end{array}$ & $\begin{array}{c}\text { Nonshift } \\
\text { workers } \\
(\mathrm{N}=233) \\
(\%)\end{array}$ & $\begin{array}{c}\text { Shift } \\
\text { workers } \\
(\mathrm{N}=327) \\
(\%)\end{array}$ & $\begin{array}{c}\text { Nonshift } \\
\text { workers } \\
(N=1746) \\
(\%)\end{array}$ \\
\hline Maternal age $\geq 35$ years & 9.8 & 9.4 & 7.0 & 8.6 \\
\hline No previous pregnancy & 41.5 & 41.4 & 39.0 & 37.6 \\
\hline $\begin{array}{l}\text { Previous deliveries without an adverse } \\
\text { pregnancy outcome }\end{array}$ & 17.0 & 28.4 & 31.3 & 35.1 \\
\hline Previous adverse pregnancy outcome ${ }^{a}$ & 41.5 & 30.2 & 29.7 & 27.3 \\
\hline Menstrual irregularity & 9.8 & 6.2 & 13.2 & 9.1 \\
\hline Regular smoking & 21.9 & 14.6 & 12.3 & 12.4 \\
\hline Alcohol intake & 39.0 & 43.4 & 43.9 & 42.8 \\
\hline Intake of drugs in the first trimester ${ }^{b}$ & 26.3 & 31.6 & 30.7 & 25.8 \\
\hline $\begin{array}{l}\text { Common cold or fever in the first } \\
\text { trimester }\end{array}$ & 19.5 & 12.4 & 17.7 & 15.5 \\
\hline
\end{tabular}

a Previous induced abortion, miscarriage, preterm delivery, malformed child, or stillbirth.

b Vitamins and tonics not included.

in workroom air (17) or peaks had been higher than the threshold limit value. Exposure to solvents did not differ much between the shift and nonshift groups.

When the relation between shift work and malformations was studied, physical work load, exposure to noise and solvents, and temporariness of employment were adjusted for in the analyses.

The mothers who had been in temporary shift work during early pregnancy had experienced more previous adverse pregnancy outcomes and were more often regular smokers than the mothers in temporary nonshift work or in regular work. More women in shift work had had menstrual irregularities than those in nonshift work. (See table 3.) Table 4 presents the maternal characteristics that were adjusted for in the analyses.

The matching procedure had not correlated the case and noncase series with respect to shift work, and therefore the data were analyzed as independent series to enhance efficiency $(18,19)$. Confidence intervals for the crude odds ratios were calculated with the modified Cornfield method $(20,21)$. The adjusted odds ratio estimates and their confidence intervals were calculated from results of unconditional logistic regression analyses, which were executed with the SAS software system (22). The independent variables were entered into the models as binary codes, or category indicators were used. Before the final models were fit, stratified analyses were performed to judge whether the stratum-specific estimates of the effect of shift work could be considered constant and to obtain estimates against which the modeling results could be checked.

\section{Birthweight and course of pregnancy}

The second part of the present study, on birthweight and course of pregnancy, was based on the noncase
Table 4. Matched odds ratio estimates of all birth defects pooled for maternal characteristics among all the 1475 casenoncase pairs.

\begin{tabular}{|c|c|}
\hline Maternal characteristic & Odds ratio ${ }^{a}$ \\
\hline $\begin{array}{l}\text { Maternal age } \geq 35 \text { years }^{b} \\
\text { Birth order greater than three } \\
\text { Two or more previous induced abortions }^{c} \\
\text { Previous miscarriage }^{c} \\
\text { Previous stillbirthc } \\
\text { Previous malformed child } \\
\text { Regular smoking during pregnancy } \\
\text { Alcohol intake during pregnancy } \\
\text { Intake of drugs in the first trimesterb,e } \\
\text { Common cold or fever in the first trimester }\end{array}$ & $\begin{array}{l}1.0 \\
1.2 \\
1.8 \\
1.1 \\
1.4 \\
3.8 \\
1.5 \\
1.1 \\
1.6 \\
1.8\end{array}$ \\
\hline \multicolumn{2}{|c|}{$\begin{array}{l}\text { a Calculated from data matched on time and area. } \\
\text { b Source: the Register questionnaire. } \\
\text { c Source: the records of the maternity health care center. } \\
\text { d All regular smoking compared to nonsmoking or temporary } \\
\text { smoking during pregnancy. The odds ratio was } 0.9 \text { for tem- } \\
\text { porary smoking during pregnancy, } 1.4 \text { for regular smoking } \\
\text { of less than five cigarettes daily, and } 1.5 \text { for regular smok- } \\
\text { ing of five or more cigarettes daily as compared with not } \\
\text { smoking during pregnancy. There were nine mothers who } \\
\text { had smoked over } 20 \text { cigarettes daily during pregnancy regu- } \\
\text { larly. } \\
\text { e Vitamins and tonics not included. }\end{array}$} \\
\hline
\end{tabular}

mothers' experience. This procedure has been described in more detail elsewhere $(23,24)$. Information on the noncase mothers' pregnancies was obtained from the Register questionnaires and the records of the maternity health care center.

The mother was asked in the Register interview if she had experienced a threatened abortion and what symptoms she had had. In the analyses vaginal bleeding with or without lower abdominal pain was considered an indication of a threatened abortion but not lower abdominal pain only.

An increase of at least $20 \mathrm{~mm} \mathrm{Hg}(3 \mathrm{kPa})$ in the mean arterial blood pressure between the mother's first visit to the maternity health care center and her last visit 
before delivery was considered a sign of pregnancyinduced hypertension (25).

The length of gestation was calculated from the first day of the last normal menstrual period. The small size of the noncase series did not allow a study of rare outcomes like preterm birth (length of gestation less than $259 \mathrm{~d}$ ), whose occurrence was $2.6 \%$ (27 mothers) among those who had worked during most of their pregnancy. Instead, the occurrence of pregnancies that were shorter than $280 \mathrm{~d}$ was studied. The reference value for the definition of a small baby for his or her gestational age was the tenth percentile birthweight of the babies of the same sex born to mothers in nonshift work in the same gestational age group. The applied gestational age groups were $<37$ weeks, $37-39$ weeks, $40-41$ weeks, and $\geq 42$ weeks. (For more details on these outcomes see references 23,24 , and 26.)

Seventeen of the 1475 noncase mothers had twin births, and for one woman information on the number of fetuses was missing. These 18 mothers were excluded from the second part of the study. Of the remaining mothers, 267 had not worked during pregnancy, 146 had worked only temporarily, and 1044 had worked regularly throughout most of their pregnancy. A total of 178 mothers had done shift work regularly and 22 temporarily. For the mothers who had been in shift work throughout most of their pregnancy, the median duration of gestation at the termination of work was $242 \mathrm{~d}$ with a lower quartile (Q1) of $223 \mathrm{~d}$ and an upper quartile (Q3) of $251 \mathrm{~d}$, and in nonshift work the median was 248 (Q1 225, Q3 252) d, respectively. In regular shift work the reason for stopping was maternity leave for $39 \%$ of the mothers, sick leave for $32 \%$, and the rest had other reasons, including vacation, or the reason was unknown. In nonshift work the respective percentages were 45 and 27.

When the occurrence of threatened abortion was studied, all the mothers who had worked were part of the analyses, but, when other aspects of pregnancy were under consideration, only mothers who had worked throughout most of their pregnancy were included. The mothers' socioeconomic class and agricultural work were controlled by the same restrictions that were used in the study of birth defects, and the same features of work were adjusted for in the analyses.

For threatened abortion the possible confounders maternal age, parity, outcome of previous pregnancies, history of menstrual irregularity, intake of drugs, alcohol consumption, and smoking were controlled in the analyses. For pregnancy-induced hypertension maternal age, parity, outcome of previous pregnancies, alcohol intake, and smoking were adjusted for. The models for length of gestation included the covariates maternal age, parity, outcome of previous pregnancies, history of menstrual irregularity, alcohol intake, and smoking. In the study of the occurrence of babies small for their gestational age maternal age, parity, outcome of previous pregnancies, maternal prepregnancy weight less than $50 \mathrm{~kg}$, alcohol intake, and smoking were controlled for.

The estimates and confidence limits for the crude risk ratios were calculated according to the chi-square function procedure of Miettinen \& Nurminen (21). The estimates of the adjusted risk ratios were calculated from the results of binomial regression analyses executed with the generalized linear interactive modeling (GLIM) program and the macros written by Wacholder (27). Independent variables were defined and analyses were performed that corresponded to the procedures used to study birth defects. The effect of shift work on vaginal bleeding and shortened length of gestation (less than 280 d) was not homogeneous when divided into strata according to noise exposure [test for heterogeneity of risk ratio (28) for vaginal bleeding $\mathrm{X}^{2}=4.7$ $(P=0.03)$ and for shortened length of gestation $\left.\mathrm{X}^{2}=5.8(\mathrm{P}=0.02)\right]$, and some indication of corresponding heterogeneity was found for pregnancyinduced hypertension $\left(\mathrm{X}^{2}=2.4, \mathrm{P}=0.12\right)$. Therefore the estimates of the effect of shift work on vaginal bleeding, pregnancy-induced hypertension, and shortened length of gestation were presented separately for strata according to noise exposure, and the concerned product terms were included in the models. No other noteworthy signs of heterogeneity were found in the data, the smallest P-value being 0.15 .

\section{Results}

\section{Malformations}

When all the birth defects were pooled, the crude odds ratio for shift work in the first trimester of pregnancy was 0.9 with a $95 \%$ confidence interval $(95 \% \mathrm{CI})$ of $0.7-1.2$, and the adjusted analysis yielded similar estimates. The crude and adjusted odds ratios for the separate malformation groups under study were unity or very close to it (table 5). When analyzed using the groups restricted to the nonagricultural workers in the two socioeconomic classes of lower-level employees with administrative and clerical occupations and manual workers, the adjusted overall odds ratio estimate was 0.9 (95\% CI 0.7-1.1). In addition, the estimates for the specific malformation groups were very similar to those obtained in the unrestricted analyses.

\section{Vaginal bleeding (threatened abortion)}

In the group of mothers who had done shift work during pregnancy, the occurrence of vaginal bleeding was $12 \%$, and in the nonshift group $9 \%$ had experienced symptoms of threatened abortion (risk ratio 1.3, $95 \%$ CI $0.8-1.9)$. The crude risk ratio for shift work and threatened abortion in the first trimester was $1.3(95 \%$ CI $0.7-2.1$ ). When the mothers' occupations were considered, it was revealed that the mothers who had done shift work in manufacturing and related occupations had an elevated risk of vaginal bleeding when 
compared with the mothers in nonshift work in manufacturing (table 6).

In manufacturing, $82 \%$ of the mothers in shift work had been exposed to a noise level of around $80 \mathrm{~dB}$ $\mathrm{L}_{\text {Aeq ( } 8 \mathrm{~h})}$ or higher as against $54 \%$ of the mothers in nonshift work. Exposure to noise modified the relation between shift work and the occurrence of vaginal bleeding. The risk ratio for shift work among the mothers who had worked in a noisy environment was $3.0(95 \%$ CI $1.2-7.5)$, but the risk for shift work was not elevated in the case of noiseless work environments (table 7). When work conditions and maternal background characteristics were taken into account, the adjusted risk ratio for shift work in a noisy environment was $1.8(95 \%$ CI $0.7-4.6)$, and for shift work in a noiseless environment the adjusted risk ratio was 0.8 (95\% CI 0.5- 1.4). When the analysis was restricted to the nonagricultural workers in the two socioeconomic classes of lower-level employees with administrative and clerical occupations and manual workers, the adjusted risk ratio for shift work in a noisy environment was $1.8(0.7-4.8)$, and for shift work in a noiseless environment the corresponding value was $0.9(95 \%$ CI $0.5-1.5)$.

\section{Pregnancy-induced hypertension}

The occurrence of pregnancy-induced hypertension was $9 \%$ among the mothers who had been in shift work and $7 \%$ among those who had not worked in shifts (risk ratio $1.2,95 \%$ CI $0.7-2.0$ ). The risk was elevated among the mothers who had done two- or three-shift work in a noisy environment; but, without noise exposure, the mothers in shift work had experienced no more pregnancy-induced hypertension than the mothers with normal daywork (table 8). The adjusted risk ratio for shift work in a noisy environment was 2.2 (95\% CI $0.7-6.5$ ), and for noiseless shift work it was $1.0(95 \% \mathrm{CI} 0.5-2.0)$. The restricted analyses yielded an adjusted risk ratio of $1.9(95 \%$ CI 0.6-5.6) for an association between shift work in a noisy environment and pregnancy-induced hypertension, and the adjusted risk ratio for shift work in a noiseless environment was 1.1 (95\% CI 0.6-2.3).

\section{Length of gestation and birthweight}

In all, for $39 \%$ of the mothers in shift work, the length of gestation was less than $280 \mathrm{~d}$, whereas the corresponding percentage in nonshift work was $44 \%$

Table 5. Mothers in shift work and those in nonshift work in the first trimester of pregnancy according to whether their baby was a case or noncase.

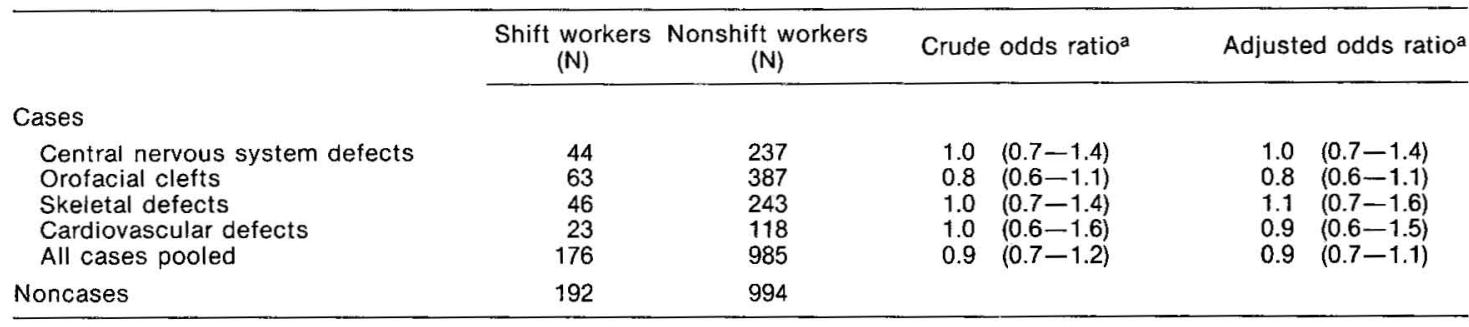

a $95 \%$ confidence interval in parentheses.

Table 6. Vaginal bleeding (threatened abortion) and shift work according to the mothers' occupations.

\begin{tabular}{|c|c|c|c|c|c|}
\hline \multirow{2}{*}{$\begin{array}{l}\text { Major } \\
\text { occupational } \\
\text { group }\end{array}$} & \multirow{2}{*}{$\begin{array}{l}\text { Number } \\
\text { of } \\
\text { mothers }\end{array}$} & \multicolumn{2}{|c|}{$\begin{array}{l}\text { Vaginal } \\
\text { bleeding }\end{array}$} & \multirow{2}{*}{$\begin{array}{l}\text { Crude } \\
\text { risk } \\
\text { ratio }\end{array}$} & \multirow{2}{*}{$\begin{array}{l}95 \% \\
\text { confidence } \\
\text { interval }\end{array}$} \\
\hline & & $\mathrm{N}$ & $\%$ & & \\
\hline \multicolumn{6}{|c|}{$\begin{array}{l}0 \text { (technical, physical science, } \\
\text { social science, humanistic, and } \\
\text { artistic work) \& } 1 \text { (administrative, } \\
\text { managerial, and clerical work) }\end{array}$} \\
\hline $\begin{array}{l}\text { Shift work } \\
\text { Nonshift work }\end{array}$ & $\begin{array}{r}97 \\
473\end{array}$ & $\begin{array}{l}10 \\
43\end{array}$ & $\begin{array}{r}10.3 \\
9.1\end{array}$ & 1.1 & $0.6-2.1$ \\
\hline \multicolumn{6}{|c|}{$\begin{array}{l}2 \text { (sales work), } 5 \text { (transport and } \\
\text { communication work) \& } 8 \text { (service work) }\end{array}$} \\
\hline $\begin{array}{l}\text { Shift work } \\
\text { Nonshift work }\end{array}$ & $\begin{array}{r}59 \\
280\end{array}$ & $\begin{array}{r}5 \\
30\end{array}$ & $\begin{array}{r}8.5 \\
10.7\end{array}$ & 0.8 & $0.3-1.8$ \\
\hline \multicolumn{6}{|c|}{$6 / 7$ (manufacturing and related work) } \\
\hline $\begin{array}{l}\text { Shift work } \\
\text { Nonshift work }\end{array}$ & $\begin{array}{r}33 \\
113\end{array}$ & $\begin{array}{l}8 \\
9\end{array}$ & $\begin{array}{r}24.2 \\
8.0\end{array}$ & 3.0 & $1.3-7.0$ \\
\hline \multicolumn{6}{|c|}{$\begin{array}{l}3 \text { (agriculture, forestry, and fishing) } \\
\& 9 \text { (work not elsewhere classified) }\end{array}$} \\
\hline $\begin{array}{l}\text { Shift work } \\
\text { Nonshift work }\end{array}$ & $\begin{array}{r}9 \\
122\end{array}$ & $\overline{9}$ & $\begin{array}{l}0.0 \\
7.4\end{array}$ & . & -4.5 \\
\hline
\end{tabular}

a According to reference 14 .

$b$ There were two mothers in shift work and two mothers in nonshift work with missing data on the symptoms. 
Table 7. Vaginal bleeding (threatened abortion) among the mothers with and those without exposure to noise in shift or nonshift work during pregnancy.

\begin{tabular}{|c|c|c|c|c|c|}
\hline & \multirow{2}{*}{$\begin{array}{l}\text { Number } \\
\text { of } \\
\text { mothers }\end{array}$} & \multicolumn{2}{|c|}{$\begin{array}{l}\text { Vaginal } \\
\text { bleeding }\end{array}$} & \multirow{2}{*}{$\begin{array}{l}\text { Crude } \\
\text { risk } \\
\text { ratio }\end{array}$} & \multirow{2}{*}{$\begin{array}{l}95 \% \\
\text { confidence } \\
\text { interval }\end{array}$} \\
\hline & & $N$ & $\%$ & & \\
\hline \multicolumn{6}{|l|}{ Noisy environment ${ }^{b}$} \\
\hline \multicolumn{6}{|l|}{ Shift work } \\
\hline $\begin{array}{l}\text { Any shift work } \\
\text { Two-shift work } \\
\text { Three-shift work }\end{array}$ & $\begin{array}{r}34 \\
26 \\
6\end{array}$ & $\begin{array}{l}9 \\
8 \\
1\end{array}$ & $\begin{array}{l}26.5 \\
30.8 \\
16.7\end{array}$ & $\begin{array}{l}3.0 \\
3.5 \\
1.9\end{array}$ & $\begin{array}{l}1.2-7.5 \\
1.4-8.8 \\
0.3-8.7\end{array}$ \\
\hline Nonshift work & 68 & 6 & 8.8 & & \\
\hline \multicolumn{6}{|l|}{ Noiseless environment } \\
\hline \multicolumn{6}{|l|}{ Shift work } \\
\hline $\begin{array}{l}\text { Any shift work } \\
\text { Two-shift work } \\
\text { Three-shift work } \\
\text { Other shift work }\end{array}$ & $\begin{array}{r}164 \\
95 \\
10 \\
59\end{array}$ & $\begin{array}{r}14 \\
7 \\
1 \\
6\end{array}$ & $\begin{array}{r}8.5 \\
7.4 \\
10.0 \\
10.2\end{array}$ & $\begin{array}{l}0.9 \\
0.8 \\
1.1 \\
1.1\end{array}$ & $\begin{array}{l}0.5-1.6 \\
0.4-1.6 \\
0.2-4.5 \\
0.5-2.3\end{array}$ \\
\hline Nonshift work & 920 & 85 & 9.2 & & \\
\hline
\end{tabular}

a There were two shift workers and two nonshift workers with missing data on the symptoms.

b Level of noise an 8-h equivalent continuous A-weighted sound level of around $80 \mathrm{~dB}$ or higher. Two mothers had been in another type of shift work, and they had not had vaginal bleeding.

Table 8. Pregnancy-induced hypertension and shift work among the mothers with and those without occupational exposure to noise throughout most of their pregnancy.

\begin{tabular}{|c|c|c|c|c|c|}
\hline & \multirow{2}{*}{$\begin{array}{l}\text { Number } \\
\text { of } \\
\text { mothers }\end{array}$} & \multicolumn{2}{|c|}{$\begin{array}{l}\text { Pregnancy-induced } \\
\text { hypertension }\end{array}$} & \multirow{2}{*}{$\begin{array}{l}\text { Crude } \\
\text { risk } \\
\text { ratio }\end{array}$} & \multirow{2}{*}{$\begin{array}{c}95 \% \\
\text { confidence } \\
\text { interval }\end{array}$} \\
\hline & & $\mathrm{N}$ & $\%$ & & \\
\hline \multicolumn{6}{|l|}{ Exposure to noise ${ }^{b}$} \\
\hline Two- or three-shift work & 28 & 6 & 21.4 & 2.4 & $0.8-6.4$ \\
\hline Nonshift work & 66 & 6 & 9.1 & & \\
\hline \multicolumn{6}{|l|}{ No noise exposure } \\
\hline \multicolumn{6}{|l|}{ Shift work } \\
\hline $\begin{array}{l}\text { Two- or three-shift work } \\
\text { Other shift work }\end{array}$ & $\begin{array}{l}92 \\
55\end{array}$ & $\begin{array}{l}6 \\
4\end{array}$ & $\begin{array}{l}6.5 \\
7.3\end{array}$ & $\begin{array}{l}0.9 \\
1.0\end{array}$ & $\begin{array}{l}0.4-1.9 \\
0.4-2.5\end{array}$ \\
\hline Nonshift work & 798 & 58 & 7.3 & & \\
\hline
\end{tabular}

a There were two shift workers and two nonshift workers with missing data on blood pressure.

b Level of noise an 8-h equivalent continuous A-weighted sound level of around $80 \mathrm{~dB}$ or higher. One mother had been in another type of shift work and had not had pregnancy-induced hypertension.

(crude risk ratio $0.9,95 \%$ CI $0.7-1.1$ ). Table 9 shows the distributions of the gestational ages of the babies according to whether their mothers were in shift or nonshift work. In a noisy environment, $57 \%$ of the mothers in shift work had a gestation shorter than $280 \mathrm{~d}$, and for mothers in nonshift work this percentage was 37 (crude risk ratio $1.5,95 \%$ CI $1.0-2.4$, and adjusted risk ratio $1.4,95 \% \mathrm{CI} 0.9-2.1$ ). For nonagricultural workers in the two socioeconomic classes of lower-level employees with administrative and clerical occupations and manual workers the corresponding adjusted risk ratio was $1.3(95 \% \mathrm{CI}$ $0.8-2.0$ ).

The tenth percentile birthweight of the babies born to mothers who had been in two- or three-shift work was $2940 \mathrm{~g}$; for the babies born to mothers who had done another type of shift work, the tenth percentile was $2900 \mathrm{~g}$; and, for the babies born to mothers with normal daily work, the tenth percentile was $3000 \mathrm{~g}$ (table 9).

In a noiseless environment, the crude risk ratio for the mothers in shift work giving birth to babies that were small for their gestational age was $1.4(95 \% \mathrm{CI}$ $0.9-2.2$ ) (table 10). The restriction of the study group to nonagricultural workers in the socioeconomic categories of lower-level employees with administrative and clerical occupations and manual workers yielded an adjusted risk ratio of 1.5 (95\% CI $1.0-2.4)$.

\section{Placental weight}

The mean placental weight was 631 (SD 132) $\mathrm{g}$ for the mothers in shift work and 611 (SD 125) $\mathrm{g}$ for the mothers in nonshift work. In all, $5 \%$ of the mothers in shift work had placentas weighing $400 \mathrm{~g}$ or less as against $4 \%$ of the mothers in nonshift work (risk ratio $1.2,95 \%$ CI $0.6-2.5$ ). 


\section{Discussion}

The analyses produced no indication of a teratogenic risk in connection with shift work. In light of the study data twofold or greater risks appeared implausible for all of the examined structural malformations. (See table 5.)

One-fourth of the mothers who had been in twoor three-shift work were in manufacturing and related occupations. (See table 1.) In manufacturing, the crude risk of threatened abortion was elevated for shift work, but some $80 \%$ of these mothers had also been exposed to noise at a level of around $80 \mathrm{~dB} \mathrm{~L}_{\mathrm{Aeq}(8 \mathrm{~h})}$ or higher. In the study data, shift work alone was not related to the occurrence of threatened abortion, but, in a noisy work environment, the mothers in shift work showed indications of an elevated risk of both this outcome and of pregnancy-induced hypertension. In addition, shift work and noise together appeared to shorten the length of gestation, but the data did not allow an evaluation of the occurrence of preterm delivery.

The occurrence of threatened abortion or pregnancyinduced hypertension showed no associations with twoor three-shift work in environments in which the level of noise was clearly less than $80 \mathrm{~dB} \mathrm{~L} \mathrm{~L}_{\text {Aeq }(8 \mathrm{~h})}$. The women in other types of shift work had mainly done periodic work in nursing occupations, and the level of noise in their work had been low. The risks of threatened abortion, pregnancy-induced hypertension, or shortened length of gestation were not elevated among these women. However, the study population was small, and the data were compatible with a broad range of possibilities.

The study mothers who had been in shift work had a slightly elevated risk of giving birth to babies that were small for their gestational age when the babies' birthweights were compared with the birthweights of the babies born to the mothers in nonshift work, and this excess of small babies was not necessarily related to exposure to noise. It is not unlikely that the work conditions during the last months of pregnancy are the most relevant with respect to birthweight. Therefore only mothers who had worked throughout most of their pregnancy were included when birthweight was studied. Half of the mothers in shift work had already stopped working around the middle of the 35 th week (as calculated from the first day of the last normal menstrual period), while the mothers in nonshift work usually worked a little longer, half of them having stopped by the middle of the 36 th week. At the time when the study data were collected, Finnish legislation stated that a pregnant woman should normally start her maternity leave 24 workdays (ie, around 29 days

Table 9. Birthweight by the gestational age of the babies according to whether their mothers were in shift or nonshift work.

\begin{tabular}{|c|c|c|c|c|}
\hline \multirow{2}{*}{$\begin{array}{l}\text { Gestational age } \\
\text { of the babies }\end{array}$} & \multicolumn{2}{|c|}{ Babies } & \multicolumn{2}{|c|}{ Birthweight (g) } \\
\hline & $\mathrm{N}^{\mathrm{a}}$ & $\%$ & Median & $\begin{array}{c}\text { Tenth } \\
\text { percentile }\end{array}$ \\
\hline \multicolumn{5}{|l|}{$<37$ weeks } \\
\hline \multicolumn{5}{|l|}{ Shift work } \\
\hline $\begin{array}{l}\text { Two- or three-shift work } \\
\text { Other shift work }\end{array}$ & $\begin{array}{l}1 \\
2\end{array}$ & $\begin{array}{l}0.8 \\
3.6\end{array}$ & $\begin{array}{l}3000 \\
2465\end{array}$ & . \\
\hline Nonshift work & 24 & 2.8 & 2605 & 875 \\
\hline \multicolumn{5}{|l|}{$37-39$ weeks } \\
\hline \multicolumn{5}{|l|}{ Shift work } \\
\hline $\begin{array}{l}\text { Two- or three-shift work } \\
\text { Other shift work }\end{array}$ & $\begin{array}{l}45 \\
20\end{array}$ & $\begin{array}{l}37.8 \\
35.7\end{array}$ & $\begin{array}{l}3500 \\
3285\end{array}$ & $\begin{array}{l}2770 \\
2625\end{array}$ \\
\hline Nonshift work & 347 & 40.7 & 3400 & 2930 \\
\hline \multicolumn{5}{|l|}{$40-41$ weeks } \\
\hline \multicolumn{5}{|l|}{ Shift work } \\
\hline $\begin{array}{l}\text { Two- or three-shift work } \\
\text { Other shift work }\end{array}$ & $\begin{array}{l}59 \\
29\end{array}$ & $\begin{array}{l}49.6 \\
51.8\end{array}$ & $\begin{array}{l}3650 \\
3790\end{array}$ & $\begin{array}{l}3020 \\
3000\end{array}$ \\
\hline Nonshift work & 429 & 50.4 & 3660 & 3150 \\
\hline \multicolumn{5}{|l|}{$\geq 42$ weeks } \\
\hline \multicolumn{5}{|l|}{ Shift work } \\
\hline $\begin{array}{l}\text { Two- or three-shift work } \\
\text { Other shift work }\end{array}$ & $\begin{array}{r}14 \\
5\end{array}$ & $\begin{array}{r}11.8 \\
8.9\end{array}$ & $\begin{array}{l}3620 \\
4000\end{array}$ & $\begin{array}{l}3250 \\
3700\end{array}$ \\
\hline Nonshift work & 52 & 6.1 & 3750 & 3140 \\
\hline \multicolumn{5}{|l|}{ Total } \\
\hline \multicolumn{5}{|l|}{ Shift work } \\
\hline $\begin{array}{l}\text { Two- or three-shift work } \\
\text { Other shift work }\end{array}$ & $\begin{array}{r}119 \\
56\end{array}$ & $\begin{array}{l}100 \\
100\end{array}$ & $\begin{array}{l}3570 \\
3620\end{array}$ & $\begin{array}{l}2940 \\
2900\end{array}$ \\
\hline Nonshift work & 852 & 100 & 3540 & 3000 \\
\hline
\end{tabular}

a There were three shift workers and 14 nonshift workers with missing data on the length of gestation. 
Table 10. Babies small for their gestational age and maternal shift work in a noiseless environment ${ }^{a}$ among all the women who worked throughout most of their pregnancy and among those nonagricultural workers who worked throughout most of their pregnancy in the two socioeconomic classes of lowerlevel employees with administrative and clerical occupations and manual workers.

\begin{tabular}{llc}
\hline Work group & $\begin{array}{c}\text { Total } \\
\text { number } \\
\text { of babies }\end{array}$ & $\begin{array}{c}\text { Babies small for } \\
\text { gestational age }\end{array}$ \\
\end{tabular}

All mothers who worked

throughout most of

their pregnancy

Shift work

Any shift work

Two- or three-shift work

Other shift work

Nonshift work

$\begin{array}{rrr}146 & 20 & 13.7^{\mathrm{b}} \\ 91 & 12 & 13.2 \\ 55 & 8 & 14.6 \\ 771 & 74 & 9.6\end{array}$

Nonagricultural lower-level employees and manual workers

Shift work

Any shift work

Two- or three-shift work Other shift work

Nonshift work

$\begin{array}{rrr}141 & 18 & 12.8 \\ 87 & 10 & 11.5 \\ 54 & 8 & 14.8 \\ 597 & 55 & 9.2\end{array}$

a An 8-h equivalent continuous $A$-weighted sound level of $<80$ dB.

b Crude risk ratio 1.4 (95\% confidence interval $(95 \% \mathrm{Cl}$ ) $0.9-2.2$ ], adjusted risk ratio $1.4(95 \% \mathrm{Cl} 0.9-2.2)$.

c Crude risk ratio 1.4 (95\% $\mathrm{Cl} 0.8-2.3)$, adjusted risk ratio 1.5 (95\% Cl $1.0-2.4)$.

when Sundays and holidays are included) prior to the estimated date of her delivery. More study mothers in shift work had stopped working before the beginning of maternity leave than those in nonshift work.

Only a few of the mothers in shift work were in the categories of own-account (ie, self-employed) workers or upper-level employees with administrative, managerial, professional and related occupations according to the used socioeconomic classification (14). Moreover, none of the mothers in shift work had been involved in farming, which explained the fact that the group in nonshift work included relatively more mothers with a moderate physical work load. (See table 2.) In addition to comparing the groups of all mothers in shift and nonshift work, further analyses were restricted to nonagricultural workers in the two socioeconomic classes of lower-level employees with administrative and clerical occupations and manual workers. The use of these selection criteria aimed at comparisons in which occupational aspects, other than work in shifts, would be more similar and, hence, the categories of work more comparable with respect to potential determinants of risk. In addition, possible selection for certain types of employment is a cause for concern. In the restricted analyses the compared mothers would be expected to have more similar pregnancy outcomes if they had not had different work schedules. (Compare reference 29.) The restricted ana- lyses produced results similar to those obtained with the more heterogeneous data.

In Finland, shift work usually involves rotating work schedules (13). The employee in rotating shift work must adapt each time that the schedule changes, and many bodily functions and systems which are circadian in nature can be disturbed (30). The study mothers in shift work reported more irregularities in menstruation (see table 3), but the possible relation between circadian rhythm and reproduction is not well understood (3).

The published studies provide some evidence of adverse effects of shift work, especially rotating shift work or irregularly changing work schedules, on pregnancy $(1-5,7,8)$, but the results include inconsistencies. The analyses of the present study produced indications that rotating shift work could be harmful for pregnancy. Altogether, the available research data are not ample. Thus further studies on the possible effects of different work schedules on pregnancy are needed.

\section{Acknowledgments}

I wish to thank S Greenland, DrPH, and K Kurppa, $\mathrm{MD}$, for their valuable comments, Ms T Suomela and Ms R Vesanto-Paavola for their skillful technical assistance, and the Finnish Work Environment Fund for its financial support.

\section{References}

1. Uehata T, Sasakawa N. The fatigue and maternity disturbances of night workwomen. J Human Ergol (Tokyo) 1982;11:465-74.

2. Axelsson G, Lutz C, Rylander R. Exposure to solvents and outcome of pregnancy in university laboratory employees. Br J Ind Med 1984;41:305-12.

3. Axelsson G, Rylander R, Molin I. Outcome of pregnancy in relation to irregular and inconvenient work schedules. $\mathrm{Br}$ J Ind Med 1989;46:393-398.

4. McDonald AD, McDonald JC, Armstrong B, et al. Fetal death and work in pregnancy. Br J Ind Med 1988; 45:148-57.

5. Mamelle N, Laumon B, Lazar P. Prematurity and occupational activity during pregnancy. Am J Epidemiol 1984;119:309-22.

6. Saurel-Cubizolles MJ, Kaminski M. Pregnant women's working conditions and their changes during pregnancy: a national study in France. Br J Ind Med 1987;44: 236-43.

7. McDonald AD, McDonald JC, Armstrong B, Cherry NM, Nolin AD, Robert D. Prematurity and work in pregnancy. Br J Ind Med 1988;45:56-62.

8. Armstrong BG, Nolin AD, McDonald AD. Work in pregnancy and birth weight for gestational age. $\mathrm{Br} \mathrm{J}$ Ind Med 1989;46:196-199.

9. Kurppa K, Holmberg PC, Hernberg S, Rantala K, Riala R, Nurminen T. Screening for occupational exposures and congenital malformations: preliminary results from a nationwide case-referent study. Scand J Work Environ Health 1983;9:89-93.

10. Saxén L. Twenty years of study of the etiology of congenital malformations in Finland. In: Kalter H, ed. Is- 
sues and reviews in teratology; vol 1. New York, NY: Plenum Publishing Corporation, 1983:73-110.

11. Holmberg PC, Nurminen M. Congenital defects of the central nervous system and occupational factors during pregnancy: a case-referent study. Am J Ind Med 1980; $1: 167-76$.

12. Kurppa K, Rantala K, Nurminen $T$, Holmberg PC, Starck J. Noise exposure during pregnancy and selected structural malformations in infants. Scand J Work Environ Health 1989;15:111-16.

13. Kauppinen-Toropainen $\mathrm{K}$, Vartia-Huomanen $\mathrm{M}$, Heiskanen J, Hyyppä M, Hänninen V, Ilmarinen J. Vuorotyö ja epämukava työaika [Shift work and disagreeable work times]. Helsinki: Institute of Occupational Health, 1981.

14. Central Statistical Office of Finland. Ammattiluokitus: yrkesklassificering: classification of occupations 1980. Helsinki: Central Statistical Office of Finland, 1981.

15. Nurminen T, Lusa S, Ilmarinen J, Kurppa K. Physical work load, fetal development and course of pregnancy. Scand J Work Environ Health 1989;15:404-414.

16. Holmberg PC, Kurppa K, Riala R, Rantala K, Kuosma E. Solvent exposure and birth defects: an epidemiologic survey. In: Ulfvarson U, Riihimäki V, ed. Safety and health aspects of organic solvents. New York, NY: Alan R Liss Inc, 1986:179-85.

17. American Conference of Governmental Industrial Hygienists. Threshold limit values for chemical substances in workroom air adopted by the American Conference of Governmental Hygienists for 1981. Cincinnati, OH: American Conference of Governmental Industrial Hygienists, 1981.

18. Miettinen OS. The matched pairs design in the case of all-or-none responses. Biometrics 1968;24:339-52.

19. Rothman KJ. Modern epidemiology. Boston, MA: Little, Brown and Company, 1986.

20. Cornfield J. A statistical problem arising from retrospective studies. In: Neyman J, ed. Proceedings of the third
Berkeley symposium on mathematical statistics and probability. Berkeley/Los Angeles, CA: University of California Press, 1956;4:135-48.

21. Miettinen $\mathrm{O}$, Nurminen M. Comparative analysis of two rates. Stat Med 1985;4:213-26.

22. SAS Institute Inc. SAS user's guide: statistics. 5th ed. Cary, NC: SAS Institute Inc, 1985

23. Nurminen T, Kurppa K. Office employment, work with video display terminals, and course of pregnancy: reference mothers' experience from a Finnish case-referent study of birth defects. Scand J Work Environ Health 1988;14:293-8.

24. Nurminen T, Kurppa K. Authors' reply: on using the reference subjects' experience of a case-referent study for purposes other than the original one [Letter to the editor]. Scand J Work Environ Health 1989;15:156-8.

25. Anderson GD, Sibai BM. Hypertension in pregnancy. In: Gabbe SG, Niebyl JR, Simpson JL, ed. Obstetrics: normal and problem pregnancies. New York, NY: Churchill Livingstone Inc, 1986:819-63.

26. Nurminen T, Kurppa K. Occupational noise exposure and course of pregnancy. Scand J Work Environ Health 1989;15:117-24.

27. Wacholder S. Binomial regression in GLIM: estimating risk ratios and risk differences. Am J Epidemiol 1986; 123:174-84.

28. Rothman KJ, Boice JD Jr. Epidemiologic analysis with a programmable calculator. Boston, MA: Epidemiology Resources Inc, 1982.

29. Miettinen OS. Theoretical epidemiology. New York, NY: John Wiley \& Sons, 1985.

30. Winget CM, LaDou J. Rotational shift work. In: Zenz C, ed. Developments in occupational medicine. Chicago, IL: Year Book Medical Publishers Inc, 1980:221-34.

Received for publication: 28 March 1989 